\title{
An Investigation of the Learning Strategies as Bias Factors in Second Language Cloze Tests
}

\author{
Parviz Ajideh \\ English Language Department, University of Tabriz, Iran \\ E-mail: Parvizaj@gmail.com \\ Massoud Yaghoubi-Notash \\ English Language Department, University of Tabriz, Iran \\ E-mail: Masoud.yaghoubi@gmail.com \\ Abdolreza Khalili (Corresponding author) \\ English Language Department, University of Tabriz, Iran \\ E-mail: Abdolrezaa.khalili@gmail.com
}

Doi:10.7575/aiac.alls.v.8n.2p.91

Received: 17/02/2017

URL: http://dx.doi.org/10.7575/aiac.alls.v.8n.2p.91

Accepted: 10/04/2017

\begin{abstract}
The present study investigated the contribution of the EFL students' learning strategies to the explanation of the variance in their results on language tests. More specifically, it examined the role of these strategies as bias factors in the results of English cloze tests. Based on this aim, first, 158 intermediate EFL learners were selected from among 324 language learners of a private language institute in Urmia (Iran) as the participants of the study based on their results on a proficiency test. Second, the selected participants respectively received Oxford's (1990) Strategy Inventory for Language Learning (SILL) and the cloze test of the study for the assessment of their learning strategies and English cloze test performance during two sessions in a one-week period. The standard multiple regression was employed for data analysis. The results of the study showed that, there were significant positive correlations between the learners' metacognitive strategies and cognitive strategies and their cloze test performance. Based on these results, it was argued that, the learners' learning strategies may be systematic test bias factors in second language cloze tests. The results of the present study may have useful practical implications for the EFL teachers and syllabus designers. Moreover, these results may provide certain theoretical guidelines for second language testing specialists.
\end{abstract}

Keywords: individual learner differences, learning strategies, test bias, test performance

\section{Introduction}

There is considerable variation among language learners regarding their success in language acquisition (Ellis, 2004). This variation is limited to the rate of acquisition for the children who are acquiring their native language. That is, although children differ in the speed of acquiring their mother tongue, they achieve perfect mastery of every aspect of that language (Bley-Vroman, 1988; Clark, 2009). However, this is not true for second language learners. As BleyVroman (1988) noted, most of these learners do not achieve a native-like competence in the use of the second language. According to him:

The general characteristics of foreign language learning tend to the conclusions that the domain-specific language acquisition of children ceases to operate in adults, and in addition, that foreign language acquisition resembles general adult learning in fields for which no domain-specific learning system is believed to exist (p. 25).

Therefore, in the case of second language acquisition, the variation involves both the learners' rate and ultimate level of achievement (Ellis, 2004, 2008). According to Ellis (2004), the differences in achievement among second language learners may stem from three general sets of factors including: social, cognitive, and affective factors. As he further argued, since the cognitive and affective factors lie inside the language learner, the researchers have investigated them as individual learner differences. These differences are "enduring personal characteristics that are assumed to apply to everybody and on which people differ by degree" (Dörnyei, 2005, p. 4). They are "factors specific to individual learners which may account for differences in the rate at which learners learn and their level of attainment" (Richards \& Schmidt, 2010, p. 278).

Horwitz (2000) noted that, the investigation of the individual learner differences has always been a major concern in the field of applied linguistics. However, as she argued, there has been an evolutionary and noticeable change regarding the terms that are used to refer to these differences. According to her: 
The terms good and bad, intelligent and dull, motivated and unmotivated have given way to a myriad of new terms such as integratively and instrumentally motivated, anxious and comfortable, field independent and field sensitive, auditory and visual (p. 532).

As Ellis (2008) stated, the investigation of individual learner differences has been motivated by different purposes. According to him, some of the studies have tried to identify the language learners who are likely to be more successful in studying certain foreign languages in comparison with the others (e.g. Carrol, 1981). Other studies have tried to determine the relationship between different individual characteristics and second language acquisition (e.g. Gliksman, Gardner \& Smythe, 1982). Finally, a number of studies have investigated the individual learner differences as potential sources of bias in language learners' test performance (e.g. Hansen \& Stanfield, 1981). That is, these differences have been examined as systematic sources that influence the validly of the inferences that are made based on the test results (Bachman, 1990).

A review of the related literature (e.g. Bialystok, 1990; Chamot \& Rubin, 1994; Cohen, 1998; Oxford, 1989, 1990; Winne, 1995) shows that, among the individual learner differences, learning strategies have been extensively investigated by the SLA researchers. However, most of the studies of the learning strategies have investigated them as good language learners' characteristics (e.g. Huang \& Van Naersson, 1985; Naiman, Fröhlich, Stern, \& Todesco, 1978; Rubin, 1975) and have ignored their role as test bias factors. Moreover, the few studies which have dealt with this issue (e.g. Purpura, 1997) have focused on the correlation between these strategies and certain proficiency tests. That is, they have not provided sufficient information about the contribution of each of these variables to the explanation of the variance in the results of different tests of language including the cloze tests. In the English as a Foreign Language (EFL) context of Iran, the empirical studies of the learning strategies have followed a similar trend. More specifically, there is a lack of research regarding the role of the learning strategies as sources of test bias in the results of the tests of the second language.

The present study was an attempt to deal with the mentioned gaps of the literature regarding the learning strategies. Based on this aim, it investigated the role of Iranian intermediate-level male EFL learners' learning strategies as test bias factors in their performance on the cloze tests. Following this line of research, the study tried to answer the following research question:

1. Is there any relationship between the EFL learners' learning strategies and their cloze test performance?

\section{Review of the Related Literature}

\subsection{Learning Strategies}

Learning strategies have been defined by several SLA researchers. According to Oxford (1989, p. 237), these strategies are the "behaviors or actions which learners use to make language learning more successful, self-directed and enjoyable". Subsequently, she noted that, effective learner strategies "make learning easier, faster, more enjoyable, more self-directed, more effective, and more transferable to new situations" (Oxford, 1990, p. 8). Similarly, Weinstein, Husman, and Dierking (2000) stated that, learning strategies "include any thoughts, behaviors, beliefs, or emotions that facilitate the acquisition, understanding, or later transfer of new knowledge and skills" (p. 727). Ellis (2008) pointed out that, these strategies "define the approach learners adopt in learning a second language and are influenced directly by learners' explicit beliefs about how best to learn" (p. 703).

In providing a comprehensive definition of these strategies, Oxford (1999) stated that, learner strategies involve:

Specific actions, behaviors, steps, or techniques that students use to improve their own progress in developing skills in a second or foreign language. These strategies can facilitate the internalization, storage, retrieval, or use of the new language (p. 518).

Moreover, in a more specific definition of these strategies, Cohen (1998) argued that:

Language learning strategies include strategies for identifying the material that needs to be learned, distinguishing it from other material if need be, grouping it for easier learning (e.g., grouping vocabulary by category into nouns, verbs, adjectives, adverbs, and so forth), having repeated contact with the material (e.g., through classroom tasks or the completion of homework assignments), and formally committing the material to memory when it does not seem to be acquired naturally (whether through rote memory techniques such as repetition, the use of mnemonics, or some other memory technique) (p. 5).

As Bialystok (1990) and Oxford $(1990,1993,1996)$ pointed out, a consideration of all of the provided definitions of the learning strategies shows that, learners employ these strategies in a conscious way in order to achieve certain goals in language learning. Similarly, Cohen (1998) stated that, the learner strategies are "learning processes which are consciously selected by the learner" (p. 4).

\subsection{The Taxonomies of Learning Strategies}

As Ellis (2008) stated, the taxonomies provided by Oxford (1990), and O'Malley and Chamot (1990) are two of the most commonly employed learner strategy taxonomies. According to him, Oxford's (1990) taxonomy is "hierarchal, with a general distinction made between direct and indirect strategies, each of which is then broken down into a number of subcategories" (p. 705). In defining these strategies Oxford (1990) stated that: 
Direct strategies require the mental processing of the language whereas indirect strategies provide indirect support for language learning through focusing, planning, evaluating, seeking opportunities, controlling anxiety, increasing cooperation and empathy and other means (p. 181).

In this taxonomy, the direct strategies include: memory, cognitive, and compensation strategies and the indirect strategies include: metacognitive, affective, and social strategies.

The second taxonomy by O'Malley and Chamot (1990) includes three categories of strategies including: cognitive, metacognitive, and socio-affective strategies. According to Ellis (2008), in this taxonomy:

Cognitive strategies are the strategies involving the analysis, transformation, or the synthesis of learning materials. On the other hand, Metacognitive strategies are the strategies involving an attempt to regulate learning through planning, monitoring, and evaluating. Finally, socio-affective learning strategies are the strategies concerning the ways in which learners interact with the other users of the second language (p. 705).

\subsection{Test Bias}

According to Bachman (1990), the individuals' scores on different tests may be influenced by both a group of personal characteristics such as cognitive style and ambiguity tolerance, and a number of group characteristics including race and ethnic background. As he further noted, unlike the random factors which have an unpredictable and transient effect on the learners' scores, the personal or individual characteristics influence the learners' scores regularly. However, as he explained, these characteristics are not part of the language ability that the language tests measure, and as a result, are regarded to be systematic sources that influence the validly of the inferences that are made based on the test results. As he stated, the "systematic differences in test performance that are the result of differences in individual characteristics other than the ability being tested" (p. 271) are sources of test bias. In other words, a test or a single test item is biased "if its scores are consistently too high or too low, for an individual test taker or a group of test takers" (Richards \& Schmidt, 2010, p. 53).

As Bachman (1990) pointed out, the studies of test bias are essential in the field of language testing since they provide a better understanding of the validity of the language tests. According to him, these studies " raise questions about the extent to which language abilities as constructs are independent of the content and context of the language use elicited in their measurement" (p. 279). Moreover, as he explained, these studies may help us judge about the measurement value of the different tests as instruments for testing the language ability. Furthermore, as he noted, they may help us to determine the characteristics of successful language learners and the role of the individual learner differences in the process of language acquisition. Finally, as Farhady (1982) argued, these studies may help us redefine the construct of language ability.

\subsection{Cloze Test}

According to Richards and Schmidt (2010), the cloze test is "a technique for measuring reading comprehension as well as overall language ability" (p. 85). As they further explained, in a cloze test "words are deleted from a reading passage at regular intervals, leaving blanks" (p. 85). Similarly, Farhady, Ja "farpur, and Birjandi (1994) argued that, the cloze procedure is a measure of a language learner's "reading comprehension in general and language processing ability in particular" (p. 253). In a more specific definition, they argued that, the cloze procedure involves "a passage of appropriate difficulty (determined by readability formulas) and of appropriate length (220-250) words with every seventh word deleted" (p. 257).

\section{Method}

\subsection{Design of the Study}

As Creswell (2011) pointed out, the correlational research design takes two main forms including; the explanatory design and the prediction design. In explaining the prediction design he stated that:

The purpose of the prediction design is to identify variables that will predict an outcome or criterion. In this form of research the researcher identifies one or more predictor variables and a criterion or outcome variable. A predictor variable is a variable which is used to make a forecast about an outcome in correlational research....The outcome being predicted in correlational research, however, is called the criterion variable (p. $341)$.

An examination of the purpose, data collection, and data analysis of the present study shows that, it employed a quantitative approach and was conducted based on a predictive correlational design in which the learning strategies were the predictor variables and the learners' performance on the cloze test was the criterion variable.

\subsection{Participants}

In the present study, 158 intermediate EFL learners were selected from among 324 language learners of a private language institute in Urmia (Iran) as the participants of the study based on their results on the Objective Placement Test (Lesley, Hansen, \& Zukowski, 2003). The selected participants: were male, raged in age from 15 to 26, and had 2 to 3 years of language studies in the language institute. They were from Urmia and were native speakers of Azeri. In order to select these participants, first, the researchers determined the mean value of the 324 language learners' results on the proficiency test of the study. Second, they selected the learners whose score were within 1 Standard Deviation (SD) below and above the mean value of the group. 


\subsection{The Instruments and Materials of the Study}

The following instruments and materials were employed in the present study:

\subsubsection{Proficiency Test}

The determination of the proficiency level and the homogeneity of the selected participants are essential in order to guarantee the validity of the inferences that are made based on the results of the empirical studies in the field of second language acquisition (Mackey \& Gass, 2016). The present study tried to determine the relationship between the intermediate EFL learners' learning strategies and their test performance. Based on this aim, the Objective Placement Test, from New Interchange Passages Placement and Evaluation Package (Lesley, Hansen, \& Zukowski, 2003) was employed in order to select the participants of the study. This test consisted of four parts: Listening, Grammar, Vocabulary, and Reading. The Listening section involved 20 recorded items. The Grammar section had 30 items. The Vocabulary section consisted of 30 items and the Reading section had 20 items.

\subsubsection{The Learning Strategy Inventory}

Based on the aims of the study, Oxford's (1990) Strategy Inventory for Language Learning (SILL) was employed in order to assess the participants' learning strategies. According to Oxford (1990), the items of this questionnaire represent six categories of strategies including: memory, cognitive, compensation, metacognitive, affective, and social strategies. This questionnaire involves 50 items that are scored on a 5-point Likert scale (i.e. $1=$ Never or almost never true of me; $2=$ Usually not true of me; $3=$ Somewhat true of me; $4=$ Usually true of me; $5=$ Always or almost always true of me). As Oxford (1990) stated, the higher scores in each category show a higher rate of the use of the relevant strategies by the learners. Moreover, as Oxford (2001) argued, the results of various empirical studies have shown that, the reliability and validity indices of SILL are satisfactory.

\subsubsection{The Cloze Test of the Study}

As Farhady, Ja 'farpur, and Birjandi (1994) noted, the results of empirical experiments have shown that, cloze tests with 25-30 items have acceptable validity and reliability indices. According to them, "considering the 7 th word deletion rate and 25 to 30 blanks, the length of the cloze passage would be somewhere between 175 to 210 words" (p. 254). However, as they explained, it is "an accepted principle to leave the first and the last sentences of the cloze texts intact" (p. 255). As they concluded, adding the number of words in these two sentences "would lengthen the cloze passage to 220-250 words" (p. 255).

Based on these issues, a 25-item researcher-made multiple-choice cloze test was employed in order to test the participants' cloze test performance in the present study. The cloze passage was selected from among the reading texts of Intermediate Select Readings (Lee \& Gundersen, 2011). This passage was 220 words in length. The researchers employed the 7th word deletion method in order to develop the 25-blank cloze passage of the study. The participants were supposed to answer the items of this test during 45 minutes.

In order to guarantee the validity and reliability of this test, it was piloted with 75 male EFL learners with similar characteristics to the participants of the study. Since the cloze passage was selected from among the reading texts of the source book of the present study, its content validity was guaranteed. However, in order to determine the empirical (concurrent) validity of the test, the results of the selected 75 learners on this test were correlated with their results on the cloze section (i.e. items 1 to 25) of the Nelson Proficiency Test (Fowler \& Coe, 1976). The results of the analysis showed that, the empirical validity index of the test was .85 which, as Harris (1969) stated, is regarded to be satisfactory for researcher/teacher-made tests. Moreover, a test-retest method was employed for determining the reliability of the test items. That is, the selected learners took the test twice during a one-month period and their results were correlated. Based on the results of this analysis, the reliability of the cloze test was .87 which is satisfactory for researcher/teachermade tests (Harris, 1969).

\subsection{The Procedure of the Study}

In this study, first, 158 intermediate EFL learners were selected from among 324 language learners of a private language institute in Urmia (Iran) as the participants of the study based on their results on the Objective Placement Test (Lesley, Hansen, \& Zukowski, 2003). Second, the SILL (Oxford, 1990) was administered to the selected participants of the study in order to assess their learning strategies. It took the participants about 25 minutes to answer the items of this questionnaire. Finally, the participants received the cloze test of the study for the determination of their second language cloze test performance. The participants answered the items of this test during 45 minutes. The questionnaire and the test of the study were administered to the participants during two sessions in a one-week period. The researchers employed the Statistical Package for the Social Sciences (SPSS) Version 20 for the data analysis of the study.

\section{Results and Discussion}

\subsection{Data Analysis}

The research question of the study tried to determine the relationship between the EFL learners' learning strategies and their cloze test performance. Based on the aims of this research question, a Standard Multiple Regression test was run between the participant's results on the learning strategy inventory and their performance on the cloze test of the study. In the regression analysis, first, the assumption of multicoliniarity had to be checked. In order to check this assumption, the collinearity diagnostics including Tolerance and Variance Inflation Factor (VIF) were determined. According to Pallant (2007): 
Tolerance is an indicator of how much of the variability of the specified independent is not explained by the other independent variables in the model. If this value is very small (less than .10), it indicates that the multiple correlation with other variables is high, suggesting the possibility of multicollinearity. The other value given is the VIP, which is just the inverse of the Tolerance value ( 1 divided by Tolerance). VIF values above 10 would be a concern, indicating multicollinearity (p. 156).

The Tolerance and VIF values of the regression model for the cloze test are provided in Table 1 below:

Table 1. The collinearity diagnostics of the learners' learning strategies and cloze test performance

\begin{tabular}{lcc}
\hline Model & Tolerance & VIF \\
\hline Memory Strategies & .894 & 1.118 \\
\hline Cognitive Strategies & .966 & 1.035 \\
\hline Compensation Strategies & .919 & 1.088 \\
\hline Metacognitive Strategies & .881 & 1.135 \\
\hline Affective Strategies & .929 & 1.077 \\
\hline Social Strategies & .818 & 1.222 \\
\hline
\end{tabular}

As Table 1 shows, all of the Tolerance values of the model were more than 0.10, and all of the VIF values were less than 10. Therefore, the multicollinearity assumption was not violated. Moreover, in order to determine the outliers, the Mahalanobis distance value was checked. As Pallant (2007) noted, for a model with 6 independent variables this value should not exceed "22.46" (p. 157). The results of residuals statistics for this model are provided in Table 2 below:

Table 2. The residuals statistics of the regression model of the learners' learning strategies and cloze test performance

\begin{tabular}{lrrrrr}
\hline & Minimum & Maximum & Mean & Std. Deviation & N \\
\hline Mahal. Distance & 1.252 & 15.518 & 5.962 & 2.790 & 158 \\
\hline Cook's Distance & .000 & .140 & .007 & .014 & 158 \\
\hline
\end{tabular}

As Table 2 shows, the maximum value of the Mahalanobis distance (15.518) was less than 22.46, and therefore this assumption was not violated. Finally, in order to check the remaining assumptions, the maximum value of Cook's distance was checked. As Pallant (2007) argued, this value should be less than 1. According to Table 2, the maximum value for the Cook's distance (.140) was less than 1 and therefore none of the assumptions was violated. Since all of the assumptions of the Multiple Regression were present, the regression model of the learners' learning strategies and cloze test performance was evaluated. Table 3 below provides the summary of this model:

Table 3. The regression model summary of the learners' learning strategies and cloze test performance

\begin{tabular}{lrrrr}
\hline Model & R & R Square & Adjusted R Square & Std. Error of the Estimate \\
\hline 1 & .522 & .273 & .244 & 4.805 \\
\hline
\end{tabular}

According to Table 3, this model explains 0.273 (i.e. $R$ Square value) of the variance of the learners' performance on the cloze test. That is, this model explains 27.3 percent ( $R$ Square value multiplied by 100 , by shifting the decimal point two places to the right) of the variance in the cloze test performance. However, in order to check the statistical significance of the predictive power of the model, the results of the ANOVA test of the model had to be checked. The results of this test are provided in Table 4 below:

Table 4. The ANOVA test of the regression model of the learners' learning strategies and cloze test performance

\begin{tabular}{lclrrr}
\hline Model & Sum of Squares & df & Mean Square & F & Sig. \\
\hline Regression & 1307.680 & 6 & 217.947 & 9.441 & .000 \\
\hline Residual & 3485.687 & 151 & 23.084 & & \\
\hline Total & 4793.367 & 157 & & \\
\hline
\end{tabular}


As Table 4 shows, the predictive power of the model was not equal to 0 since the p-value of the ANOVA test .000 (marked as Sig.) was less than the level of significance .05.

Finally, in order to determine the contribution of each of the independent variables to the prediction of the variance of the cloze test results the Standardized Coefficients had to be checked. These results are provided in Table 5 below:

Table 5. The coefficients of the regression model of the learners' learning strategies and cloze test performance

\begin{tabular}{lccccc}
\hline Model & Unstandardized Coefficients & $\begin{array}{c}\text { Standardized } \\
\text { Coefficients }\end{array}$ & t & Sig. \\
\cline { 2 - 5 }$($ Constant $)$ & B & Std. Error & Beta & \\
\hline Memory Strategies & 2.522 & 2.500 & 1.009 & .315 \\
\hline Cognitive Strategies & -.040 & .044 & -.067 & -.919 & .360 \\
\hline Compensatory Strategies & .048 & .023 & .148 & 2.097 & .038 \\
\hline Metacognitive Strategies & .103 & .068 & .109 & 1.511 & .133 \\
\hline Affective Strategies & .283 & .043 & .488 & 6.603 & .000 \\
\hline Social Strategies & .042 & .065 & .046 & .645 & .520 \\
\hline
\end{tabular}

According to Table 5, the largest Beta value is .488 which is for the Metacognitive Strategies variable. Therefore, it can be argued that, this variable makes the strongest unique contribution to explaining the results of the cloze test when the variance explained by all of the other variables in the model is controlled. Moreover, since the p-value for this variable .000 (marked as Sig.) was less than the level of significance .05, it was argued that this variable made a statistically significant unique contribution to the prediction of the cloze test results. Furthermore, based on the results, Cognitive Strategies $(\mathrm{Beta}=.148, \mathrm{Sig}=.038)$ was the second variable that made a significant contribution to the results. The significant contributions of these variables to the explanation of the results of this test are respectively depicted in Figures 1 and 2 below:

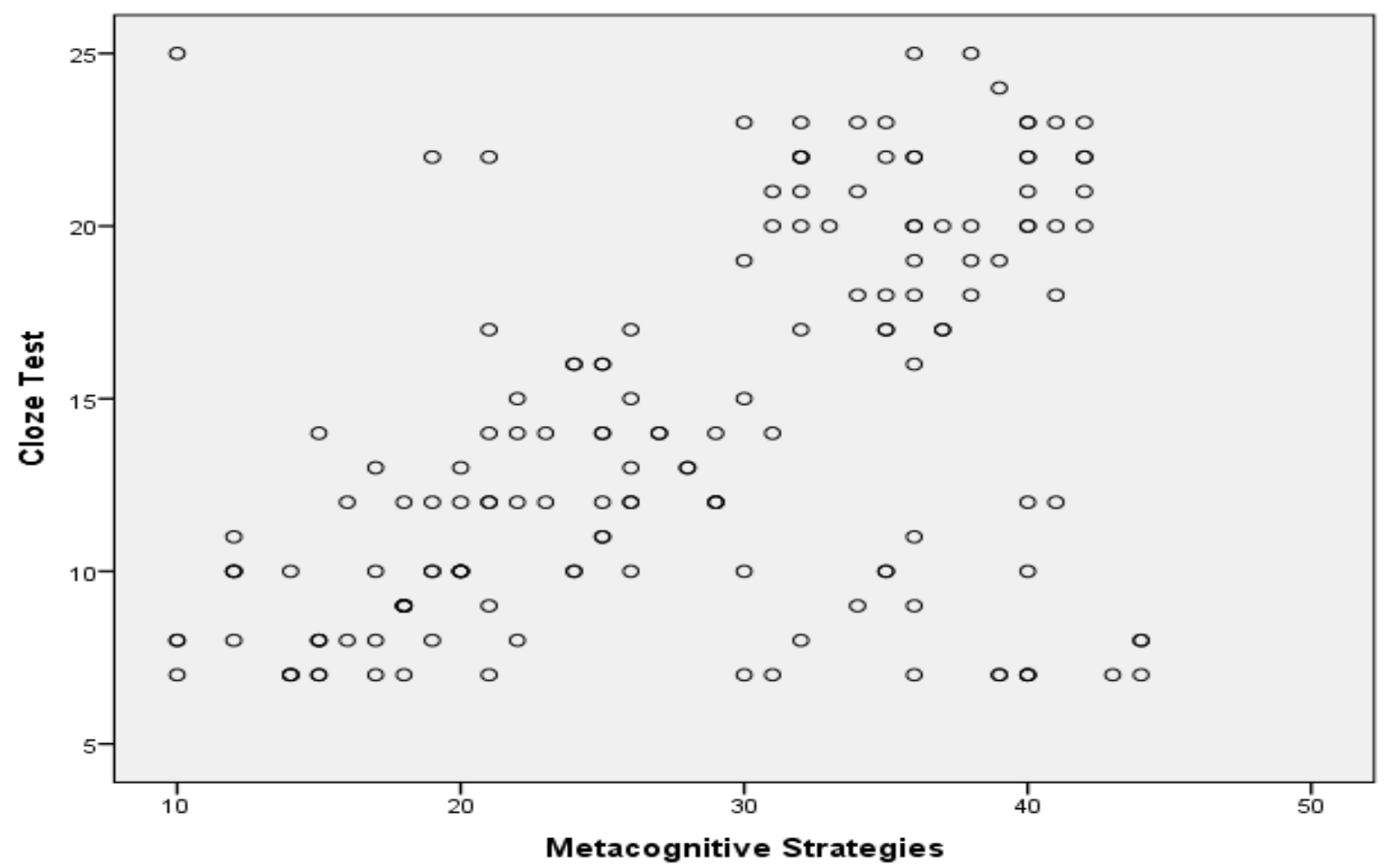

Figure 1. The Correlation between the Learners' Metacognitive Strategies and Cloze Test Performance 


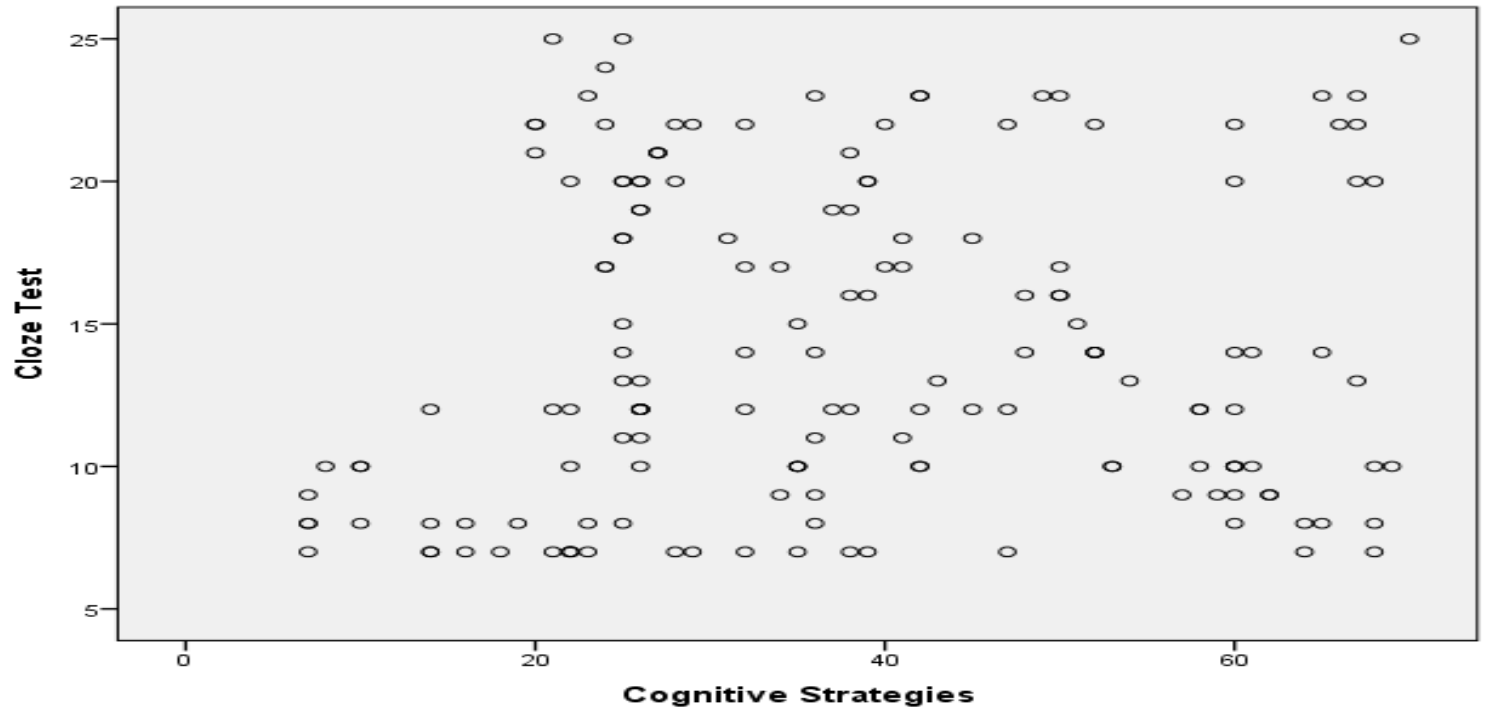

Figure 2. The Correlation between the Learners' Cognitive Strategies and Cloze Test Performance

\subsection{Discussion}

The present study tried to determine the relationship between the EFL learners' learning strategies and their cloze test performance. The results of the data analysis showed that, the learners' Metacognitive Strategies and Cognitive Strategies were respectively the first and the second variables that made significant contributions to explaining the variance in the results of the cloze test. These results are in line with the results of the studies by Purpura (1997), Phakiti (2006), and Ajideh and Gholami (2015) who have reported significant positive contributions of learner strategies to the explanation of the variance in second language test results.

According to Reiss (1983), the learners who are able to employ a wide variety of metacognitive strategies mostly have clear goals in language learning and try to learn and use the second language in a native-like way. Moreover, as Rubin (1987) argued, the metacognitive strategies encourage the language learners to pay attention to the different aspects of the reading materials and evaluate the appropriateness of the employed linguistic forms in various contexts. Furthermore, as Cohen and Chi (2001) stated, the cognitive strategies encourage the language learners to practice the different writing genres in the second language (e.g. notes, essays, \& reports) and help them to become familiar with the appropriate lexicon of these genres. Finally, as Ehrman (1990) argued, the cognitive strategies help the learners to recognize, and focus on the lexical collocations of the second language and enable them to use the language in a nativelike way.

According to Spolsky (1973), the cloze test challenges the language learners' ability to evaluate the contextual appropriateness of the different words in various texts. Moreover, as Oller (1979) stated, this kind of test challenges the learners' ability to process the second language similar to its native speakers.

Based on these issues, it can be argued that, in the present study, the participants with higher degrees of metacognitive and cognitive strategy use had a better performance on the cloze test in comparison with the others since they: consciously focused on the use of different linguistic forms in their reading materials, recognized the lexical collocations of the second language, practiced different writing genres of the second language, and tried to process and use the second language in a native-like way. Therefore, it can be concluded that, the learners' metacognitive and cognitive learning strategies may be systematic sources of test bias and affect their performance on the cloze tests of the second language.

Finally, it should be noted that, the results of the present study do not support the results of the studies by Bialystok (1981) and Politzer and McGroarty (1985) who could not find any significant correlations between the learning strategies and second language test performance.

According to Ehrman and Oxford (1989), language learners' age is one of the variables that determine their use of different learning strategies. Moreover, as Schmidt and Watanabe (2001) stated, the learners' motivation may have an impact on their strategy use. Furthermore, as Littlemore (2001) argued, the students' learning styles may determine their strategy use. In addition, the learners' strategy use may depend on their educational major (Peacock \& Ho, 2003) and language learning beliefs (Ehrman, 1990). Finally, the learners' strategy use may be influenced by their gender (Kaylani, 1996), the language being learnt (Chamot, O’ Malley, Kupper, \& Impink-Hernandez, 1987), the context of language learning (Chamot, Kupper, \& Impink-Hernandez, 1988), and the task type (Chamot et al., 1987; Chamot et. al., 1988).

According to Ellis (2008), the factors that affect the language learners' strategy use may also affect the relationship between their learning strategies and performance on different kinds of language tests. Based on these issues, it can be argued that, the difference between the results of the present study and the studies by Bialystok (1981) and Politzer and McGroarty (1985) may be related to the characteristics of their participants including: age, motivation, learning styles, beliefs, educational major, and language learning experience. Moreover, this difference may be related to the social and 
situational factors of these studies including: the learners' gender, the language being learnt, the context of language learning, and the task types of the participants.

\section{Conclusion}

The present study investigated the relationship between the EFL learners' learning strategies and their performance on the second language cloze tests. The results of the study showed that, there were significant positive correlations between the learners' metacognitive strategies and cognitive strategies and their cloze test performance. Based on these results, the EFL teachers are recommended to determine their students' learning strategies by the means of reliable and valid strategy inventories (e.g. SILL). The knowledge of the learners' strategy use will enable the teachers to provide their learners with appropriate instruction regarding the cognitive and metacognitive strategies. Moreover, the EFL syllabus designers are recommended to include certain sections in the EFL textbooks in which the learners receive suitable instruction regarding the various kinds of learning strategies. Furthermore, they have to design certain tasks in which the learners are required to employ certain learning strategies for the completion of the task. Finally, as Skehan (1989) noted, the language testing specialists are recommended to adopt a research-then-theory approach in the studies of individual learner differences in order to provide more information regarding the random, non-linear, and contextspecific role of these differences in the explanation of the variance in the results of different measures of the second language.

However, it should be noted that, there is a need for various empirical studies of individual learner differences in different learning contexts and educational settings in order to make wide-reaching conclusions about the role of these differences as test bias factors. For instance, the future studies should investigate larger samples including both male and female second language learners. Moreover, they should involve language learners from different age groups. The investigation of these personal attributes may help to answer certain questions regarding the differential development of language ability based on the learners' age and gender (Bachman, 1990). Furthermore, the future studies should involve language learners from different mother tongues, and language proficiency levels in order to provide more information regarding the non-linear and variable role of the individual learner differences in the explanation of the variance in second language tests.

\section{Acknowledgments}

The researchers express their gratitude to Dr. Javad Gholami and Dr. Zhila Mohammadnia for their help during the data collection of the present study.

\section{References}

Ajideh, P., \& Gholami, V. (2015). Investigating learning strategies as predictors of test performance. Academie Royale des Sciences D outre-Mer Bulletin des Seances, 4 (3), 183-191.

Bachman, L. F. (1990). Fundamental considerations in language testing. Oxford: Oxford University Press.

Bialystok, E. (1981). The role of conscious strategies in second language proficiency. The Modern Language Journal, 65, 24-35.

Bialystok, E. (1990). Communication strategies: A psychological analysis of second-language use. Oxford: Basil Blackwell.

Bley-Vroman, R. (1988). The fundamental character of foreign language learning. In W. Rutherford \& M. Sharwood Smith (Eds.), Grammar and second language teaching: A book of readings (pp. 19-30). New York: Newbury House.

Carroll, J. B. (1981). Twenty-five years of research in foreign language aptitude. In K. C. Diller (Ed.), Individual differences and universals in language learning aptitude (pp. 83-118). Rowley: Newbury House.

Chamot, A. U., Kupper, L., \& Impink-Hernandez, M. (1988). A study of learning strategies in foreign language instruction: Findings of the longitudinal study. McLean, Va: Interstate Research Associates.

Chamot, A. U., O’ Malley, J., Kupper, L., \& Impink-Hernandez, M. (1987). A study of learning strategies in foreign language instruction: First year report. Rosslyn, Va: Interstate Research Associates.

Chamot, A. U., \& Rubin, J. (1994). Comments on Janie Rees-Miller's “A critical appraisal of learner training: Theoretical bases and teaching implications". TESOL Quarterly, 28, 771-776.

Clark, E. V. (2009). First language acquisition (2 ${ }^{\text {nd }}$ Ed.). Cambridge: Cambridge University Press.

Cohen, A. D. (1998). Strategies in learning and using a second language. Harlow: Longman.

Cohen, A. D., \& Chi, J. C. (2001). Language strategy use survey. Minneapolis: Center for Advanced Research on Language Acquisition.

Creswell, J. W. (2011). Educational research: Planning, conducting and evaluating quantitative and qualitative research ( $4^{\text {th }}$ Ed.). New York: Pearson Education.

Dörnyei, Z. (2005). The psychology of the language learner: Individual differences in second language acquisition. Mahwah: Lawrence Erlbaum. 
Ehrman, M. E. (1990). The role of personality type in adult language learning: An ongoing investigation. In T. Parry \& C. Stansfield (Eds.), Language aptitude reconsidered (pp. 126-178). Englewood Cliffs: Prentice-Hall Regents.

Ehrman, M. E., \& Oxford, R. L. (1989). Effects of sex differences, career choice, and psychological type on adult language learning strategies. The Modern Language Journal, 73, 1-13.

Ellis, R. (2004). Individual differences in second language learning. In A. Davies \& C. Elder (Eds.), The handbook of applied linguistics (pp. 525-551). Oxford: Blackwell.

Ellis, R. (2008). The study of second language acquisition ( $2^{\text {nd }}$ Ed.). Oxford: Oxford University Press.

Farhady, H. (1982). Measures of language proficiency from the learner's perspective. TESOL Quarterly, 16(1), 43-59.

Farhady, H., Ja 'farpur, A., \& Birjandi, P. (1994). Testing language skills: From theory to practice. Tehran: SAMT Publishers.

Fowler, W. S., \& Coe, N. (1976). Nelson English language tests. London: Thomas Nelson and Sons Ltd.

Gliksman, L., Gardner, R. C., Smythe, P. (1982). The role of integrative motivation on students' participation in the French classroom. Canadian Modern Language Review, 38, 625-647.

Harris, D. P. (1969). Testing English as a second language. New York: McGraw-Hill.

Horwitz, E. K. (2000). Teachers and students, students and teachers: An ever-evolving partnership. The Modern Language Journal, 84, 523-535.

Huang, X. H., \& Van Naersson, M. (1985). Learning strategies for oral communication. Applied Linguistics, 6, 287307.

Kaylani, C. (1996). The influence of gender and motivation on EFL learning strategy use in Jordan. In R. L. Oxford (Ed.), Language learning strategies around the world: Cross-cultural perspectives (pp. 75-88). Honolulu: University of Hawaii Press.

Lee, L., \& Gundersen, E. (2011). Intermediate select readings. Oxford: Oxford University Press.

Lesly, T., Hansen, Ch., \& Zukowski, J. (2003). New interchange passages placement and evaluation package. New York: Cambridge University Press.

Littlemore, J. (2001). An empirical study of the relationship between cognitive style and the use of communication strategy. Applied Linguistics, 22, 241-265.

Mackey, A., \& Gass, S. (2016). Second language research: Methodology and design ( $2^{\text {nd }}$ Ed.). New York: Tylor and Francis.

Naiman, N., Fröhlich, M., Stern, H., \& Todesco, A. (1978). The good language learner. Toronto: Ontario Institute for Studies in Education.

Oller, J. W. (1979). Language tests at school: A pragmatic approach. London: Longman.

O’Malley, J. M., \& Chamot, A. U. (1990). Learning strategies in second language acquisition. New York: Cambridge University Press.

Oxford, R. L. (1989). Use of language learning strategies: A synthesis of studies with implications for strategy training. System, 17, 235-247.

Oxford, R. L. (1990). Language learning strategies: What every teacher should know. New York: Newbury House.

Oxford, R. L. (1993). Research on second language learning strategies. Annual Review of Applied Linguistics, 13, 175187.

Oxford, R. L. (1996). Afterword: What have we learned about language learning strategies around the world? In R. L. Oxford (Ed.), Language learning strategies around the world: Cross-cultural perspectives (pp. 247-249). Honolulu: University of Hawaii Press.

Oxford, R. L. (1999). Learning strategies. In B. Spolsky (Ed.), Concise encyclopedia of educational linguistics (pp. 518-522). Oxford: Elsevier.

Oxford, R. L. (2001). Language learning styles and strategies. In M. Celce-Murcia (Ed.), Teaching English as a second or foreign language (pp. 86-111). Boston: Heinle and Heinle.

Pallant, J. (2007). SPSS survival manual: A step by step guide to data analysis using SPSS for windows ( ${ }^{\text {rd }}$ Ed.). Berkshire: McGraw-Hill House.

Peacock, M., \& Ho, M. (2003). Student learning strategies across eight disciplines. International Journal of Applied Linguistics, 11, 1-20.

Phakiti, A. (2006). Modeling cognitive and metacognitive strategies and their relationships to EFL reading test performance. Melbourne Papers in Language Testing, 1, 53-96.

Politzer, R., \& McGroarty, M. (1985). An exploratory study of learning behaviors and their relationship to gains in linguistic and communicative competence. TESOL Quarterly, 19, 103-123. 
Purpura, J. E. (1997). An analysis of the relationships between test takers' cognitive and metacognitive strategy use and second language test performance. Language Learning, 47, 289-325.

Reiss, M. A. (1983). Helping the unsuccessful language learner. The Canadian Modern Language Review, 39, $257-266$.

Richards, J. C., \& Schmidt, R. (2010). Longman dictionary of language teaching and applied linguistics (4 ${ }^{\text {th }}$ Ed.). Edinburg: Pearson Education.

Rubin, J. (1975). What the “Good Language Learner” can teach us. TESOL Quarterly, 9, 41-51.

Rubin, J. (1987). Learner strategies: Theoretical assumptions, research history and typology. In A. Wenden \& J. Rubin (Eds.), Learner strategies in language learning (pp.15-19). New York: Prentice Hall.

Schmidt, R., \& Watanabe, Y. (2001). Motivation, strategy use, and pedagogical preferences in foreign language learning. In Z. Dörnyei \& R. Schmidt (Eds.), Motivation and second language acquisition (pp.313-359). Honolulu: University of Hawai'I Press.

Skehan, P. (1989). Individual differences in second language learning. London: Edward Arnold.

Spolsky, B. (1973). What does it mean to know a language or how do you get someone to perform his competence. In J. W. Oller \& J. C. Richards (Eds.), Focus on the learner (pp. 164-176). Rowley: Newbury House.

Weinstein, C. E., Husman, J., \& Dierking, D. R. (2000). Self-regulation interventions with a focus on learning strategies. In M. Boekaerts, P. R. Pintrich \& M. Zeidner (Eds.), Handbook of self-regulation (pp. 727-747). San Diego: Academic Press.

Winne, P. H. (1995). Inherent details in self-regulated learning. Educational Psychologist, 30, $173-187$. 